\title{
The Religious Significance of Kant's Ethics
}

\author{
by Jacqueline Mariña
}

Love never ends. But as for prophecies, they will come to an end; as for tongues, they will cease; as for knowledge, it will come to an end. For we know only in part, and we prophesy only in part, but when the complete comes, the partial will come to an end. (1 Corinthians 13:8ff.)

ttention to Kant's categorical imperative has for the most part
focused on its significance for secular moral theory. Its reli-
gious meaning has received little, if any attention at all. Yet, while it is no doubt true that Kant's categorical imperative does not, and need not, appeal to theology for its validation, this does not imply that an in-depth investigation of the categorical imperative and the cluster of issues associated with it cannot reveal deep and surprising insights into the nature of persons and what specifically about them equips them for the religious life. In this paper I would like to examine Kant's categorical imperative and the issues attending it in the context of a person's relation to God and others. ${ }^{1}$ In effect, this amounts to an attempt to assess the implications of Kantian

'This approach to Kant's ethics and its relation to religion is diametrically opposed to that of Gordon E. Michalson in his most recent book Kant and the Problem of God (Oxford: Blackwell, 1999). In this book Michalson argues that the principal thrust behind Kant's ethical theory, as well as behind Kant's understanding of religion, is one that leads to atheism. Michalson argues that there is a "principle of immanence" at work in Kant's philosophy that "is finally incompatible with theistic belief and which implicitly leaves Kant's own effort at theological mediation in shambles ... The teleological drive governing rationality's quest for satisfaction is simultaneously a drive to overcome otherworldliness in the portrayal of human destiny" (5). Michalson's claim rests on a fundamental oversight regarding Kant's philosophy.

(C) 2001, American Catholic Philosophical Quarterly, Vol. LXXV, No. 2 
moral theory on theology's understanding of the first and second great commandments. This is no doubt a huge task, one that cannot be accomplished within the confines of a single paper. What I would like to do here, however, is to sketch the main lines of relevance to religion of Kant's categorical imperative in the hope of spurring further discussion and debate.

The paper will be divided into two parts. The first part of the paper will be concerned with foundational issues. These have to do with what Kantian moral requirements reveal about the structure of human rationality, and what this rationality implies. I show that these requirements and their implications supply us with concrete and fruitful guidelines as to how we should conceive of what equips persons for the religious life. Key to this analysis is the concept of self-transcendence. I argue that Kant's understanding of the relation of the moral law to rational yet finite beings such as ourselves provides a great deal of insight into what we should expect from an analysis of self-transcendence. This conceptual work lays the groundwork for an understanding of the proper relation of the individual to God and to the neighbor.

In the second part of the paper I examine the relation of the categorical imperative to the second great commandment to love the neighbor as oneself. This part of the paper will explore the relation of the demands of the categorical imperative to the demands of Christian agapic love. I will argue that the concepts overlap to a surprising degree. Moreover, many of the conceptual resources that fill out Kant's moral theory can be fruitfully applied to a theoretical analysis of agape. Lastly, I will explore what these implications reveal about how we should love God.

He does not seem to appreciate fully enough the significance of the primacy of practical reason in Kant. According to what practical reason tells us, we are not simply the product of intra-worldly causes. From a practical point of view we are members of an intelligible world and of the Kingdom of Ends. As rational, ethical beings we know our nature to transcend the world of sense. Hence, it is only fitting that our rational hopes should lead us to expect a final destiny not tied to this world. It thus seems to me utterly wrongheaded to suppose that Kant's philosophy ultimately leads to the materialistic atheism that we find, for instance, in Marx. For a more in-depth discussion of the specific character of the postulates concerning God, the soul, and immortality to which practical reason commits us, see my article "Making Sense of Kant's Highest Good," Kant-Studien 91 (2000): 1-27. 
Self-Transcendence and the Categorical Imperative. The ability to transcend the self lies at the heart of what it means to be genuinely religious. Through this ability the individual is enabled to connect with what is other than the self. However, it not only enables the self to surpass its finitude and particularity in order to genuinely make contact with the other. It is also at the ground of a person's ability to ask questions regarding the nature of the totality of the world in which s/he and others are situated. Questions regarding such totalities lead to further questions regarding what encompasses and grounds them. But these are precisely religious questions. In order to ask such questions in the right way a person must be able to surpass her own parochial concerns. S/he must be able to understand herself as situated in a world of other rational beings whose self-fulfillment is just as important as hers. Genuine religion is the opposite of solipsism. The solipsistic individual understands the world and others in it as an extension of him or herself. These are viewed only in terms of his or her projects and concerns and how they can best be furthered. While no doubt it is also possible to ask questions regarding the totality of one's experience of the world and others from such a solipsistic perspective, to do so is a perversion of the religious impulse and blocks the possibility of genuine self-transcendence. The genuinely religious individual, on the other hand, is spurred by a need to understand the world as a place where all moral beings can perfect themselves and in this way find self-fulfillment.

For Kant the locus of self-transcendence is not speculative but practical. It is grounded in the unconditioned demand that the moral law places upon us. The nature of this unconditioned demand is such that it immediately places the self in relation to other rational selves. ${ }^{2}$ This relation is, moreover, not one in which the other is valued in terms the self's preexisting projects and concerns. Rather, the other must be valued as an end in him or herself. In order to flesh out these claims, let me first turn to some key metaethical arguments in Kant's ethics.

${ }^{2}$ As Onora O'Neill aptly notes, “despite long traditions of reading Kant as presenting a 'philosophy of the subject,' his starting point is rather that of plurality... Kant's distinctiveness lies in the fact that his discursive grounding of reason presupposes plurality, and the possibility of community; it does not presuppose 'atomistic subjects, actual communities or ideal communities" ("Vindicating Reason," in The Cambridge Companion to Kant, ed. Paul Guyer [Cambridge: Cambridge University Press, 1992], 280-308, at 308 n. 17). 
In this section I argue that the most important issue affecting a fruitful analysis of the concept of self-transcendence has to do with the nature and source of value judgments regarding the other. What are the possible grounds of our regard for the other, and what should the nature of this regard be? Can it be that the grounds on account of which we value the other affect the nature of our regard for him or her? Questions such as these are key to an understanding of the possibility of self-transcendence, since it is only insofar as I can genuinely enter into the life of the other that I can move beyond myself as a locus of concern. ${ }^{3}$ But a condition of my entering into the life of the other has to do with the nature of the value I attach to him or her.

Foundational to Kant's ethics is the insight that the ground of one's regard for the other determines the nature of this regard. There are, for Kant, two possible sources grounding our regard for the other, the empirical and the rational. Either we can care about another because we just so happen to have desires that dispose us to caring for him or her, or an a priori rational principle governing the causality of the will determines the nature of the good and hence the grounds of the worth of the other, and thus what should be desired. However, only a practical law binding all rational beings (one which all rational beings must acknowledge as binding) can be the ground of a rational and objective determination of the good. Were it impossible for practical reason to determine a priori that which is a necessary object of desire, we could only understand our desires as determined in the order of causes. Failing an account of what should, and hence can be desired, all we would have left to work with are the desires we in fact have. But such desires are facts about ourselves that supervene upon our physical constitution, and as such they are causally determined. We have those kinds of desires insofar as we are affected from without. They are particular insofar as they are the desires of an embodied being that happens to have them given a past nexus of causes that resulted in this particular physical entity having

${ }^{3}$ It is important to note that this is true not only of my relationship to other finite rational selves, but of my relationship to the divine life as well. There is very big difference between the individual that merely fears God as the one who has power over him or her, and the individual that loves God because God is good. Only the latter individual has begun to enter into the divine life, that is, has made God's ends (the unconditioned valuing of rational creatures) his own. Only the individual that comprehends the value of these ends independently (and not because they have been commanded by great power) can really enter into the divine life, since only in this way can it intelligently be said that s/he shares God's ends. 
these desires. However, if our concept of the good were to depend upon how we are affected, not only would this imply that the will is ineluctably heteronomously determined, it would also imply that the idea of the good must be thought of as variable and relative to the particular susceptibilities of sensuously affected beings. Kant notes that although our reason would be able to discern

the connection of means and intentions ... the practical maxims which follow merely as means from the concept of the good never contain anything good in itself as the object of the will but only something good for something else. In this way, the good would be only the useful, and that for which it useful must always lie outside the will, in feeling [Empfindung]. ${ }^{4}$

Since the susceptibilities of individual subjects can only be determined empirically, a universally valid concept of the good cannot be based upon them. But once such a concept is lacking, the individual is forced back in upon herself for her understanding of the good, in particular insofar as she is a body in a spatio-temporal world. Her concept of the good must then be reducible to those objects constituting her well-being because she desires them. In such a scenario, her subjectivity becomes absolute and cannot be transcended, for that which is good and which is, as such, an object of value, can be defined relative only to her given desires. Why these desires are her desires cannot receive any universally communicable rational justification-they simply are a fact of her constitution. The possibility of a genuine communication with the other and a shared outlook on what is objectively of value is thereby blocked.

Moreover, this implies that if an individual's only criterion for what is of value must have its origin in desires that are caused and are hers only because of the particular spatio-temporal locus that she occupies, it will be impossible for the individual to value the other as an end in him or herself. This is because whatever value the individual attaches to the other will hinge upon the desires that she happens to have. If this is the case, there would be no criterion of objective value establishing the worth of the other, but

${ }^{4}$ Critique of Practical Reason, trans. Louis White Beck (New York: Macmillan, 1993), 61; henceforth Prussian Academy Edition pagination will be noted immediately following the volume number in brackets: [5:59-60]. 
rather, the other's worth would hinge on the self's contingently existing desires. In such a scenario, the self becomes the arbiter of the worth of the other. But to think of myself as the arbiter of the worth of the other is precisely not to consider the other as an end in himself, that is, an individual that must claim my moral regard independently of my desires.

But Kant's claims are even stronger than this. In the second Critique he asserts that "all material practical principles are, as such, of one and the same kind and belong under the principle of self-love or one's own happiness." Material practical principles are principles constructed in order to achieve given desired ends; as such their content depends upon those ends. Their adoption thus hinges upon the existence of contingent desires making up what Kant dubs "the lower faculty of desire." Kant's claim, then, is that practical principles designed so that one can satisfy desires stemming from the lower faculty of desire are associated with the principle of self-love. Note that his claim here is an even stronger one than the already controversial claim found in the Groundwork. There Kant notes that the beneficent actions of the "friend of man," that is, the individual with a sympathetic temperament who acts from this inclination (the inner pleasure $s /$ he finds in spreading happiness around her) have no moral worth. He concedes, however, that such an individual might act without any further motive of vanity or self-interest. ${ }^{6}$ In other words, given the account in the Groundwork, it seems quite possible that an individual can be genuinely other-directed even if he acts only from inclination. In the second Critique, however, Kant tells us that all actions motivated by the lower faculty of desire are connected with self-love or one's own happiness. These two statements seem to be at odds with one another, since if this is the case the actions of the "friend of man" would then be connected with self-interest.

The reasons why the actions of the friend of man have no moral worth have been extensively discussed in the secondary literature. It is not only that policies grounded in the inclinations generally do not reliably coincide with what morality demands. We can easily imagine an individual whose sympathetic temperament has been honed so as to become a matter of habit, as Hume suggests. We can even imagine that it has been habituated to re-

${ }^{5}$ Tbid, 21 [5: 22].

${ }^{6} \mathrm{Kant}$ notes that "there are moreover, many persons so sympathetically constituted that without any motive of vanity or selfishness they find an inner satisfaction in spreading joy, and rejoice in the contentment of others which they have made possible" (Foundations of the Metaphysics of Morals, trans. Louis White Beck (Indianapolis: Bobbs-Merrill, 1959), 14 [398]. 
spond impartially. But as Barbara Herman notes, "while sympathy can give an interest in an action that is (as it happens) right, it cannot give an interest in its being right." It is one thing, however, to say that action grounded in inclination has no moral worth, and another to say that all such action is connected with self-love or the principle of furthering one's own happiness. The stronger claim is what interests us here, since this would show that the ground of one's valuing has a decisive impact upon its content. In other words, we need to show that the decision to attribute value only to the desires one happens to have has a determinate influence on the content of those desires. This influence is such that in cases wherein action is simply in accordance with the strongest desire one happens to have, the content of one's valuing never moves past the circle of one's self-concern.

Kant's analysis of non-morally motivated action as presented in the second Critique has come under a good bit of fire. For his presentation of the nature of such non-morally motivated action there seems to suggest that the object of all action grounded in the lower faculty of desire is the pleasure one expects from a desire's satisfaction. If Kant's understanding of non-morally motivated action as grounded in the principle of self-love is dependent upon this too simplistic an understanding of the psychology of desire, his analysis would thereby be invalidated. Kant notes the following:

Pleasure from the representation of the existence of a thing, in so far as it is a determining ground of the desire for this thing, is based upon the susceptibility of the subject because it depends upon the actual existence of the object ... It is practical only in so far as the faculty of desire is determined by the actual existence of the object. Now happiness is a rational being's consciousness of the agreeableness of life which without interruption accompanies his whole existence, and to make this the supreme ground for the determination of choice constitutes the principle of self-love. ${ }^{8}$

It has often been argued that Kant's portrays non-morally motivated action as hedonistic; as such he has been accused of putting forth a rather crude understanding of the psychology of action. T.H. Green, who first

${ }^{7}$ Barbara Herman, The Practice of Moral Judgment, (Cambridge: Harvard University Press, 1993), 5.

${ }^{8}$ Critique of Practical Reason, 20 [5: 22]. 
came up with this line of criticism, notes that "Kant's error lies in supposing that there is no alternative between the determination of desire by the anticipation of pleasure and its determination by the conception of a moral law." On this model of the lower faculty of desire, what moves me to do $x$ is the pleasure I expect from achieving the end of action x. Now while the deep structure of Kant's theory need not fall prey to the criticisms discussed here, in the second Critique Kant does often describe non-morally motivated action in a way that fits this pattern. Hence he writes that

if the determination of the will rests on the feelings of agreeableness or disagreeableness which he expects from any cause, it is all the same to him through what kind of representation he is affected. The only thing he considers in making a choice is how great, how long-lasting, how easily obtained, and how often repeated this agreeableness is. ${ }^{10}$

On this model, the ultimate end of non-moral action is the pleasure one expects from the objects desired. The objects of desire are themselves ultimately unimportant, since they are mere means to the achievement of the agreeableness of life.

But surely not all non-moral actions are so motivated, and in fact, the psychology of human motivation is much more complex than this. We would be hard pressed to interpret the self-destructive actions of many persons (for instance, those of women who repeatedly find themselves in abusive relationships) as motivated solely in terms of the pleasure principle. Hence, what moves me to desire $\mathrm{x}$ is often not the pleasure that I expect from realizing $\mathrm{x}$, but rather, I desire this $\mathrm{x}$ because I value it. My reasons for valuing it may, moreover, have nothing to do with either the pleasure that I expect from it or from moral considerations.

Although it would be mistaken to assume that the end of all non-moral action is pleasure, a sophisticated theory of human motivation can account for inclinations as originating in our susceptibilities to being affected from

${ }^{9}$ T.H. Green, Collected Works, vol. 2, 119, cited by Terence Irwin, "Morality and Personality: Kant and Green," in Self and Nature in Kant's Philosophy, ed. Allan Wood (Ithaca and London: Cornell University Press, 1984), 31-56, at 43.

${ }^{10}$ Critique of Practical Reason, 22 [5: 23]. 
without (pleasure and pain). ${ }^{11}$ As such, inclinations are grounded in causes lying outside the will. The specific character of these susceptibilities may be influenced by environmental and genetic factors. Moreover, while my nonmoral desires can have complex causal histories involving such factors, my ultimate aim in achieving the objects of these desires need not be the pleasure to be gotten from them. As has been pointed out numerous times in the literature, objections to the deep structure of Kant's argument often rest on a failure to distinguish between the end of an action and the reasons for adopting such an end. ${ }^{12}$ As such, while the end of non-morally motivated action need not be the pleasure one expects from an object, the reasons one has for doing $\mathrm{x}$ may involve the satisfaction of desires one has in virtue of one's susceptibilities to being affected from without. It will become clearer as we proceed that this thesis is all that Kant really needs in order to establish that all non-morally motivated action is rooted in the principle of selflove.

Even if a hedonistic theory of the lower faculty of desire is one to which Kant need not ultimately commit, his claim that all non-moral action ultimately stems from the principle of self-love is more deeply embedded in his ethical theory. An understanding of the deep structure of this claim will further illuminate why it is that only action which takes into account the unconditioned demand that the other makes really allows one to move beyond the circle of one's self-concern. We have already shown above why an individual motivated by the inclinations alone cannot value the other as an end in him/herself. This means, for instance, that insofar as the actions of the friend of man are motivated by inclination alone, they are not actions that are directed to the other taken as an end in himself. However, we need to see our way more clearly into just how such action is connected with the

${ }^{11}$ In his article, "Hedonism, Heteronomy, and Kant's Principle of Happiness," Pacific Philosophical Quarterly 70 (1989): 42-72, Andrews Reath points out that what is most significant about heteronomous actions is that they have their origin in causes lying outside the will and not that they are motivated by a desire for pleasure.

${ }^{12}$ See, for instance, Henry Allison, Kant's Theory of Freedom (Cambridge: Cambridge University Press, 1990), 103. Barbara Herman puts the matter very clearly when she notes: "Errors about these matters can come from thinking that 'motive' and 'end' (the object of action) are merely reciprocal concepts. They can be, but they are not always so. The end is that state of affairs the agent intends his action to bring about. The motive of an action, what moves the agent to act for a certain object, is the way he takes the object of his action to be good, and hence reason-giving. The motive explains his interest in the end" (The Practice of Moral Judgment, 25). 
principle of self-love. If Kant's theory is to have something significant to say about the conditions attending self-transcendence, the reasons why such actions are connected with the principle of self-love cannot be that the end toward which they are directed is pleasure.

It is possible that one's actions are directed to specific ends which are themselves not valued for the pleasure they can afford. It can at the same time be true that the reasons for the adoption of these ends are rooted in ways in which the agent has been affected in the past. But if this is the case, why is basing one's action in one's causal history alone action in accordance with the principle of self-love? The answer is not, as we have seen, that the individual who acts in accordance with such a principle is out to get pleasure. The issue rather lies in that in acting in such a way one makes one's causal history the basis of the ultimate criterion determining one's choices. In doing so one makes the self and its specific particularities the locus of the determination of what is of value. To act on the principle of satisfying those desires one simply happens to have is to act on the principle of self-love because to do so is to validate the choices of the self qua particular individual. Attitudes toward the other stemming from these desires alone, however other-directed they may seem (as in the case of the friend of man), cannot genuinely be directed toward the other qua other, that is, as an individual having a claim on our regard toward him or her irrespective of our likes and dislikes. In fact, once we recognize that the other has a moral claim on our regard toward him/her and frame our principles in accordance with such a claim, we are no longer framing our principles in light of the desires we simply happen to have.

Moreover, if it is true that insofar as the moral law exerts an unconditioned demand upon us it functions as an incentive, to frame one's principles only in light of the desires one happens to have constitutes a willful disregard of the claims of the other upon oneself. Such a willful disregard of such claims is more than self-love. It is what Kant calls self-conceit. Kant distinguishes between self-love and self-conceit in the course of his discussion of respect for the moral law:

All inclinations taken together (which can be brought under a fairly tolerable system, whereupon their satisfaction is called happiness) constitutes self-regard (solipsismus). This consists either of self-love, which is a predominant benevolence toward one's self (philautia) or of self-satisfaction (arrogantia). The former is called, 
more particularly, selfishness; the latter, self-conceit. Pure practical reason merely checks selfishness, for selfishness, as natural and active in us even prior to the moral law, is restricted by the moral law to agreement with the law; when this is done, selfishness is called rational self-love. But it strikes self-conceit down, since all claims of self-esteem which precede conformity to the moral law are null and void. For the certainty of a disposition which agrees with this law is the first condition of any worth of the person (as will soon be made clear), and any presumption [to worth] prior to this is false and opposed to the law. ${ }^{13}$

As noted above, the inclinations are in principle subjective, since they stem from the receptivity of inner sense, and owe their existence to the physical and psychological constitution of the agent. The drive toward their satisfaction is thus solipsistic, since universal validity cannot be ascribed to them. Rational self-love is the drive toward the fulfillment of these inclinations insofar as this drive is checked by the moral law. On the other hand, self-conceit consists in the attempt to ascribe universal validity to the subjective inclinations: the "propensity to make the subjective determining grounds of one's choice into an objective determining ground of the will in general can be called self-love; when it makes itself legislative and an unconditioned practical principle, it can be called self-conceit." ${ }^{14}$ While self-love consists in the drive towards the realization of ends bringing satisfaction with one's condition, self-conceit is the attempt to ascribe an absolute value to those ends. It thus involves a tendency to think of the self as the source of all value; in such a case the empirically determined desires of the individual are thought of as the ultimate criterion for establishing the value ascribed to ends.

As Andrews Reath has noted, self-conceit "turns out for this reason to be a form of value which one only achieves at the expense of others," for while self-love is a "tendency to take one's inclinations to provide sufficient reasons for one's actions," self-conceit is a "tendency to treat your inclinations as providing reasons for the actions of others, or to take your desires as 
sources of value to which they should defer." ${ }^{15}$ While rational self-love, insofar as it is checked by the moral law, allows one to view other people's inclinations as sufficient reasons for their own actions, "self-conceit would produce a form of first person egoism in which I act as though my inclinations could provide laws for the conduct of others; it expresses a desire that they serve or defer to my interests." 16 Ascribing an absolute priority to the ends of the self, the attitude of self-conceit toward others is always that of domination and manipulation. It is thereby opposed to the fundamental moral attitude, that is, the recognition of others as ends in themselves. Given that the concept of a categorical imperative is that of a law that is absolutely binding on all rational wills, it is opposed to the principle of self-conceit, which strives to make the self and its subjective desires the ground of absolute value.

While the moral law thus limits and constrains self-love to expressions that harmonize with the ends of others, it strikes down self-conceit. This is because self-conceit is the attitude in fundamental opposition to the moral law, and no reconciliation between the two is possible. Kant's description of self-conceit accords with the Christian account of the dynamics of pride, which has been traditionally understood as the root of all evils. Like pride, self-conceit is the attempt to give one's subjective desires an absolute value. Amounting to an attempt to set up the finite and conditioned self as the arbiter of all value, it is the root expression of the authority problem producing enmity with God.

The attitude of self-conceit stands in direct opposition to the autonomy of the will. The will is autonomous when and insofar it is able to judge, and to be moved by, a standard that can be rationally justified as having absolute worth. Such a standard has this kind of worth because all rational wills must recognize it. On the other hand, self-conceit is the attempt to make the conditioned desires of the finite self absolute, that is, to give them a universal validity that they cannot, in principle, have. Insofar as its principal dynamic is that of decreeing "subjective conditions of self-love as laws," it rests on a lie in the attempt to make that which is really only subjective into something objective. As such, this attitude blocks self-transcendence, that is,

\footnotetext{
${ }^{15}$ Andrews Reath, "Kant's Theory of Moral Sensibility: Respect for the Moral Law and the Influence of Inclination," Kant-Studien 80 (1989): 284-302, at 293.

${ }^{16}$ Ibid.
} 
the move beyond the finite self and its concerns toward an ability to value that which can in principle be shared by others as a standard of value.

Thus far I have shown why attitudes toward others grounded in inclination alone cannot be the ground of genuine self-transcendence. The flip side of this implies that only insofar as values are informed by an unconditioned demand is self-transcendence possible. The unconditioned demand that the other places upon us has a metaphysical basis. It is a commonplace that for Kant this metaphysical basis is rooted in the fact that the other is a rational being. While correct, this way of putting the matter obscures the deep structure and implications of Kant's ethics. For Kant rationality does not mean something like the ability to do quadratic equations, although too often Kant's meaning has been construed in just this way. It simply means the ability to recognize and take an interest in something the value of which does not depend upon an individual's subjective desires. That which has this kind of value must be recognized as such by all individuals having the capacity to transcend their particularity and subjectivity. Rationality is thus the capacity to take an interest in that which has unconditioned worth. But just what has such unconditioned worth is in fact this very capacity of moving beyond self-interest and entering into community with the other as one that must be considered an end in him or herself. The other has such worth because s/he too can transcend her merely subjective desires and enter into community. Hence the ability to enter into communion with other rational selves is just what constitutes rationality and is the ground of the claim that the person has upon another's regard. There is a surprising circularity to this claim that is not vicious. The circularity consists in the fact that rationality consists in the ability to enter into communion with the other, while the other with whom I am able to enter into communion is defined as anyone who has this same ability to transcend his or her self-concern and enter into community with others.

This point has the further consequence that while that which has unconditioned value cannot be determined aside from the community of rational selves constituting and recognizing such value, this does not mean that any arbitrary community can make a joint decision as to what constitutes worth and what does not. The only criterion for membership in the community of rational selves is the ability to transcend the circle of one's selfconcern and enter into community with the other. This rules out the validity of a particular community's stipulation regarding which selves have worth and which do not on account of how they may or may not fit with the community's self-definition and goals. Whatever particular projects or 
concerns an individual or group of individuals might have is irrelevant to the question of the regard due to them as ends in themselves. What marks individuals as having unconditioned worth is their capacity to enter into genuine relation with others. This capacity implies the ability to enter into the life of the other, to value the other as an end in him or herself and to thereby take an interest in his or her well-being.

In this section I have argued that implications of Kantian moral requirements illuminate the nature of the "metaphysical center" making persons capable of connecting with God and others. ${ }^{17}$ This metaphysical center is the capacity a person has for self-transcendence, for moving beyond the confines of his or her self-concern. It is intrinsically linked with what Kant calls "the higher faculty of desire," that is, our capacity to take an interest in the moral law and the claims that others as ends in themselves have upon us. In the next section I will compare the relation of Kant's categorical imperative to the demands of Christian agapic love. In the course of this analysis, I discuss in more depth the implications that the grounds of our attitudes toward others have upon their content. In fact, Kant's ethics is distinguished by the claim that the ground of our ascriptions of worth has a decisive impact upon just what it is we consider as having worth.

II.

Love for God and Neighbor and the Categorical Imperative. No doubt the philosophical and theological literature on the subject of agape alone is itself vast. In this section I will limit myself to an analysis of generally undisputed claims about agape, although the results of this analysis may lead into areas of controversy. In his classic study on agape Gene Outka identifies two features of agape closely related to one another. First, "agape is regard for the neighbor which in crucial respects is independent and unalterable." ${ }^{18}$ Second, "the regard is for every person qua human existent, to be distinguished from those special traits, actions, etc., which distinguish particular personalities."19 To say that agapic regard is independent means that it does not depend on any traits specific to a particular individual that the other may possess. As

\footnotetext{
${ }^{17}$ While it is clear that for Kant a doctrine of a metaphysical soul-substance is out of the question, as Kant makes clear in the second Critique, the moral law as a fact of reason carries with it the metaphysical implication of transcendental freedom.

${ }^{18}$ Gene Outka, Agape: An Ethical Analysis (New Haven: Yale University Press, 1972$), 9$.

${ }^{19} \mathrm{Ibid}$
} 
such, the quality of agapic regard is not proportioned to what the neighbor has made of him or herself and what s/he may possess. In contrast, preferential relationships such as erotic love and friendship are characterized as dependent upon their objects. Kierkegaard, for instance, claims that the person who has these kinds of preferential relations always stands in jeopardy of losing what makes the relationship of value to him or her. One cares about the specific qualities an individual may have and how these qualities mesh with one's own interests. One cares, too, about whether the other will return one's affections or esteem. This, for Kierkegaard, is the ground of the "anxiety which makes erotic love and friendship dependent upon their objects, the anxiety which can kindle jealousy, the anxiety which can bring one to despair." ${ }^{20}$ Kierkegaard also notes that while it may be possible to continue in a preferential relationship no matter how the other treats one (a relation of co-dependency like the one portrayed in Of Human Bondage comes to mind), the preferential relationship becomes impossible once the other has changed. He writes

You can also continue to love your beloved and your friend no matter how they treat you, but you cannot truthfully continue to call them beloved and friend when they, sorry to say, have truly changed. No change, however, can take your neighbor from you, for it is not your neighbor who holds you fast ... it is your love which holds your neighbor fast. ${ }^{21}$

Kierkegaard's point is that a regard for the other that is dependent upon what the other makes of him or herself, or how the other reacts, is dependent on factors outside one's control. This reveals something about the nature of this kind of regard for the other. It depends on how we are affected from without. Now the desires that we simply find ourselves having (in contrast to those we determine through considerations regarding what has objective worth) are connected with our physical constitution. Insofar as we are physical beings, we are affected from without. If my regard for the other depends upon how the other affects me, I allow my particular susceptibilities as an embodied being to determine my regard for the other. But

${ }^{20}$ Søren Kierkegaard, Works of Love, ed. and trans. Howard V. Hong and Edna H. Hong (Princeton: Princeton University Press, 1995), 66.

${ }^{21}$ Ibid., 65. 
agape, as Kierkegaard points out, is independent of how the neighbor may affect me-it is not the neighbor that holds me fast. This is also to say that my particular susceptibilities, my likes and dislikes, should have nothing to do with the reasons for my agapic regard for the other. The independence of agapic regard from how the neighbor may affect one thus connects in important ways with Kant's ethics. For Kant the proper ground of our regard for the other cannot lie in our particular susceptibilities, that is, in how the other affects us. ${ }^{22}$

The correlate of the independence of agapic regard for the other is that it is the other qua human existent that calls for my regard. Special traits and particularities of the other should not ground my regard for him or her. If my regard depends on such special traits, it is dependent upon how he or she can affect me and is thus grounded in my susceptibilities. Moreover, this kind of regard results in preferential relationships. I care for those having specific characteristics that can affect me in a certain way, and my regard is dependent upon this effect. As such, it is not unconditional. If the person changes, $\mathrm{s} /$ he can no longer be the object of my esteem.

On the other hand, regard for the other based on a prior claim of his or her value qua human existent is independent both of my susceptibilities and, correlatively, of the other's peculiarities. It is my recognition of such an $a$ priori claim that holds fast my esteem for him or her. As such, agapic regard has permanent stability and does not fluctuate. Kierkegaard notes that it is "not your neighbor who holds you fast ... it is your love which holds your neighbor fast." Such esteem for the neighbor does not depend on anything changeable about him or her. It depends, instead, upon an essential feature of his or her personhood existing prior to anything he or she has done. As such, the other is irreducibly valuable, and one's love holds the neighbor fast in the sense that it insists on recognizing those qualities essential to the other even when the neighbor may not recognize them him or herself.

A crucial implication of these features of agapic regard is that one neighbor's well-being is as important as another's. If my concern for the other cannot be grounded in the way the other can affect me and therefore in my susceptibilities, a person's idiosyncratic qualities are irrelevant to the esteem in which I must hold him or her. What is of significance is simply

${ }^{22}$ Important connections between Kant and Kierkegaard have been pointed out by Ronald M. Green in his book, Kierkegaard and Kant: the Hidden Debt (Albany: State University of New York Press, 1992). 
that quality of the other in virtue of which he or she has an irreducible claim on my concern. But such a quality is a generic endowment that does not allow me to discriminate between one person and another, and this implies that I am to regard all persons equally. In this respect it is interesting to note that Kierkegaard claims that "... if there is one other person whom you in the Christian sense love as yourself or in whom you love the neighbor, then you love all people." ${ }^{23}$ Once one has learned the secret behind valuing one person as a neighbor, one should be able to recognize and value all persons as neighbors.

Let us compare these characteristics of agapic regard with Kant's central ethical claims. The regard owed the other, according to Kant, cannot be grounded in the inclinations. The inclinations are rooted in our capacity to be affected from without. Hence the regard we owe the other cannot be grounded in our particular susceptibilities. As such, this regard cannot depend upon how the other can affect us and hence cannot depend upon his or her idiosyncratic characteristics. To ground our concern for the other in the inclinations, that is, in those desires we simply happen to have, is, according to Kant, to act in accordance with the principle of self-love. In his discourse on agape Kierkegaard, too, claims that all preferential love is simply another form of self-love. He tells us that "Christianity has misgivings about erotic love and friendship simply because preferential love in passion or passionate preference is actually another form of self-love."24

Notice the strong connection between preferential love and the ground of such regard. Preference for one person over another is grounded in their differences from one another. Because person $a$ is different from person $b$, the two people affect us in different ways. Hence our preference for one over the other is ultimately grounded in how they affect us and in how their impressions on us both satisfy and incite certain kinds of desires. Preferential love is thus ultimately rooted in the inclinations and in our capacity for being affected from without. Hence there is a very significant sense in which the ground of our regard for the other determines the content of that regard. If we base our regard for the other on how he or she affects us, our regard cannot but be of the kind that is sensitive to differences between persons. One person will be valued more highly than another because association with him or her satisfies our idiosyncratic preferences. Other-regard

${ }^{23}$ Works of Love, 21.

${ }^{24} \mathrm{Ibid}$., 53. 
grounded in inclination is of the kind that judges and discriminates between persons.

While all preferential relations are grounded in the inclinations, it would be incorrect to claim that all regard for others rooted in the inclinations must be preferential. Hume's example of a temperament that has been habituated to act sympathetically and impartially is a case in point. Nevertheless, other-regard rooted in the inclinations is not directed by the unconditioned claim the other has on our regard qua human existent. Failing guidance by an unconditioned demand, it is hard to see how a sympathetic temperament can, by itself, make its way through the maze of moral dilemmas requiring intelligence and delicacy in discernment and judgement. Such discernment requires an awareness of that which has unconditioned worth in the attempt to make decisions that impact different people in various ways. A sympathetic temperament alone, no matter how well it has been trained to be impartial, is not equipped to think (rather than feel) through issues and to respect that which has absolute worth. If a decision that ultimately respects the unconditioned and equal worth of others is indeed reached through a sympathetic temperament alone, this can only have been by accident.

Thus far I have shown in what sense preferential love such as eros and friendship correspond to regard for the other rooted in the inclinations. In the course of my analysis I have also demonstrated the relations existing between the ground of our regard for the other and the content of such regard in respect of inclination and preferential relations. I have not yet discussed the ground of agapic regard and how it relates to the ground of the categorical imperative's unconditional demand regarding the other. This is a much more complicated issue. Why, according to Kant, does the other make a claim on our unconditioned regard? While the answer to this question can be discussed at length, for our purposes we need only to mention what was noted before, namely, the other is of unconditioned worth because of his or her capacity for self-transcendence and ability to enter into community with the other. Moreover, we can value the other because we ourselves have such a capacity for self-transcendence. This capacity presupposes Kant's notion of transcendental freedom, which, he tells us, is the ratio essendi of the moral law. If it is to be possible for us to value that which is objectively valuable and hence should be valued, then our valuings cannot be determined by causes lying outside of our will. If this is Kant's answer, how does it mesh with Christianity's understanding of the ground of agapic re- 
gard? The answer is complicated by the fact that this question is one of the most contested issues regarding agape.

There are two basic positions that can be taken in this regard. The first has been taken by Brunner, Nygren and others: agape cannot be grounded in the recognition of the worth of essential characteristics that all persons share. ${ }^{25}$ They argue that if agape is dependent upon pre-existing traits having objective worth, then the element of grace in agape is not really grace. Just as God's love for humans is unmerited grace, so humans are commanded to love one another as God has loved them, regardless of their characteristics and habits. If agape were in fact to have a ground, that is, if it were to be the proper response to an objective worth, it would lose its unmerited character and hence its close ties to grace. This understanding of agape has the most affinities with a grounding of Christian ethics in divine commands.

The second position identifies agapic regard as the proper response to essential features that all human beings share. This position is more closely tied with Catholic approaches to Christian ethics. One example of such an approach is that of Jacques Maritain, who makes reference to a "metaphysical center" in the other that claims our acknowledgement of value. As Outka correctly notes, that agapic regard is the proper response to essential features of the other by no means vitiates grace. The idea that there is something about the neighbor that makes a claim on our regard for him or her need not imply "worth apart from God or which God merely recognizes. An account of characteristics to be appraised will not necessarily treat them as simply belonging to the person in some utterly autonomous way or as traits which the person has attained by his own initiative." ${ }^{26}$ This is especially true insofar as it is stressed that the very possession of these traits is due to the person's having been created by God in God's image.

While it is no doubt true that Kant's ethics cannot be understood to coincide with the first position outlined above, I do not find any significant

${ }^{25}$ See Outka's discussion in Agape: An Ethical Analysis, chapter 6.

${ }^{26}$ Earlier in this passage Outka makes the following important observation: "It is also hard to see how every scheme involving appraisal of generic characteristics all men have and perhaps equally share can be held always to undermine grace. That question depends on what those objectively valuable characteristics are, and how they are known. One might still relate such characteristics to belief in God's action. They could be tied, for instance, to a doctrine of creation which need not idolize the creature or require that grace be explained or justified by something outside itself. Any generic worth or value already existent may precisely reflect God's sovereign creative action" (ibid., 159). 
points of conflict between it and the second position. Both emphasize that the regard due the other is grounded in certain essential features shared by all persons. No doubt the second position on agape moves beyond Kant's central points of emphasis in stressing that the possession of the kind of nature to which agapic regard is due results from having been created in God's image. But as long as both parties focus on human nature as that which grounds the regard due the other, there need not be substantial disagreement on this point.

If however, the agapic demand is understood as grounded only in the will of God, then there may be substantial divergences between the Christian understanding of agape and Kant's ethics. While it is no doubt true that for Kant the moral law and the will of God must be conceived of as conforming to one another, the deeper question is whether the will of God must be thought of and defined in terms of the moral law, or whether the moral law must be thought of in terms of the will of God. The problem is, therefore, which must be prior in the order of knowledge, knowledge of the will of God, or knowledge of the moral law? If knowledge of the will of God is made the condition of our knowledge of the moral law, we would then have no criterion through which we could judge whether such a will was a holy one. In other words, we would have no criterion through which to judge whether the will which reveals itself is that of God or the devil. If we cannot, through the use of rational criteria, understand the absolute worth of God's commands, then the only reason left us to adopt God's ends as our own is that God has power over our weal and our woe. Kant notes that if we do not think of God's will in moral terms, "the only remaining concept of the divine will is made up of the attributes of desire for glory and dominion combined with the awful conceptions of might and vengeance, and any system of ethics based on them would be directly opposed to morality." ${ }^{27}$ We would then have to think of ourselves as servile, only relating to God as the one who has power over us. This amounts to nothing less than idolatry. Kant notes that

Though it does indeed sound dangerous, it is in no way reprehensible to say that every human being creates a God for himself, nay, must make himself such a God according to moral concepts (and must add those infinitely great attributes which characterize a 
Being capable of exhibiting, in the world, an object commensurate with Himself), in order to honor in Him the One who created him. For in whatever manner a being has been made known to him by another and described as God, yea, even if such a being had appeared to him (if this is possible), he must first of all compare this representation with his ideal in order to judge whether he is entitled to regard it and to honor it as a divinity. Hence there can be no religion springing from revelation alone, i.e., without first positing that concept, in its purity, as a touchstone. Without this all reverence for God would be idolatry. ${ }^{28}$

Without first presupposing morality as a touchstone for our understanding of God, we could not relate to God as the God of love, that is to say, as the One who really enters into communion with the other, and who makes this communion possible. ${ }^{29}$ To think of God only in terms of the one who has power over us would not only block the possibility of a true communication between God and the human being, it would leave each person locked in on her own private and subjective quest for happiness. For unless God's will is understood in terms of a universally communicable account of the good, it would be only such a quest, which by its very nature cannot move beyond the self and that which gratifies it, that would bind the individual to do the will of God. Such a concept of God and how He relates to us thus precludes the possibility of self-transcendence.

If an individual acts "out of love for God," or "out of a desire to do God's will," this way of formulating the matter leaves open the crucial questions of why God's will should be obeyed, or of why God should inspire our love. These questions can only be appropriately answered in terms of an a priori rational account of the good, with which God's will must be thought to conform. Only when such an account has been given can we justify why

${ }^{28}$ Immanuel Kant, Religion within the Limits of Reason Alone, trans. T.M. Greene and Hoyt H. Hudson (New York: Harper \& Row, 1960) 157 [6: 169].

${ }^{29} \mathrm{Kant}$ tells us that "Godliness comprises two determinations of the moral disposition in relation to God: fear of God is this disposition in obedience to His commands from bounden duty (the duty of a subject), i.e., from respect for the law; love of God, on the other hand, is the disposition to obedience from one's free choice and from approval of the law (the duty of a son). Both involve, therefore, over and above morality, the concept of a supersensible Being provided with the attributes which are requisite to the carrying out of that highest good which is aimed at by morality but which transcends our powers" (ibid., 170 [6:183]). 
doing the will of God should be of value to us. If Kant is correct, which I believe he is, then we cannot relate properly to God unless we have already grasped the worth of the second great commandment. ${ }^{30}$

Purdue University

West Lafayette, Indiana

${ }^{30}$ I would like to thank Carl Schrag and Phil Quinn for their many useful comments on this paper. 